\title{
Pigeons' Feed at their Various Stages
}

\author{
M. Ashraful Kabir \\ Department of Biology, Saidpur Cantonment Public College, Nilphamari, Bangladesh
}

*Corresponding Author: M. Ashraful Kabir, Department of Biology, Saidpur Cantonment Public College, Nilphamari, Bangladesh

\begin{abstract}
The system for serving traditional feed is common in pigeons. In some commercial farms they provide modern or standard feed ratio but this scenario is very few. Need to provide feed depending on pigeons' quality. For all stages in pigeon should maintain the ratio of protein and fat. Racing, flying and showing breeds need different type of feed ratio. Not only the breeds but also various stages like growing, moulting, breeding, laying and hatching stages, we should provide different mix of feed. For better productivity rearers will know the feed value and daily requirement. Hatching stage pigeons need an extra feed at the mid day. In Bangladesh we need to establish an enriched pigeon feed shop. Basically, poultry feed is not allowed for pigeons.
\end{abstract}

Keywords: Pigeon; Feed; Component; Value.

\section{INTRODUCTION}

Energy producing food stuffs and then chemical reaction within the organism is important for pigeons' physiology. Proper feed and maintenance prevent all diseases. A good and experienced rearer sould maintain their pigeon farm scientifically. In our country a lot of poultry shop but its hygiene is not good. All pigeon rearers buy pigeons' feed from these shops. Many rearers and other people go there with dirty dresses and hands which pollutes poultry or pigeons' feed. Most rearers do not have good knowledge on pigeons' feed. Sometimes they mix poultry feed and it gains pigeon huge weight and ultimately it showed bulky which is the root cause for less productivity. Poultry feed dissolve with normal feed then fungus grows. Oyster dust larger than $6 \mathrm{~mm}$ is must for its digestion. Brick dust and other sand particles are supplied to the pigeons which will be of course germ free. For reproduction and flying purpose we should supply different ratio of feed. Room temperature and humidity need to maintain always. Room size, ventilation, number of pigeons and amount of feed are needed to observe. For controlling fungal growth in feed sometimes we should dry feed by sunlight. Growing, moulting and breeding birds should provide feed in a different ways. Age-wise pigeons' group is good for providing its exact feed ratio. In our prehistoric time pigeons took feed only mustard, paddy and paddy rice but now all fancy pigeons are habituated to take polished feed. Rearers collect their local or fancy pigeons without any knowledge. Timely feed supply is important for their production. Some rearers supply more vitamins for better production. For this, though, sometimes pigeon show huge productivity but it's not good for the future. Maximum farms are not well cleaned in the country. Pigeons eat more in colder months. 25 breeding pairs will eat $3 \mathrm{~kg}$ feed daily. Many breeders separate their pigeon in October and re-mate in April (Kabir 2013b). If exotic and local pigeons are crossed its progenies are good as meat (Kabir 2013a). The objective of this study is to ensure the feed ratio in various stages of pigeons for good output.

\section{FEED IN BANGLADESH}

Wheat: Indigenous and hybrid both are available in market. Winter wheat is white and summer is red. Soft and hard wheat both are sold by businessman. If pigeons show loose motion which might cause for the presence of insecticides. In this case need to wash wheat then dry in sunlight properly. Barley carries bristles, it's also a problem. 
Corn: Fine netting corn should supply for pigeons. When pigeons' nourish its chick need more fine granules of corn. Corn is higher with carbohydrate but low in protein. Maize are three types- red, orange and popcorn (Teurlings 1923).

Pea: Whole pea is most use in Bangladesh for large-sized pigeons. This is good to quick crop filling. Bean and peas are not good for the young (Teurlings 1923). There are thousands of peas in the world which carries 22-23 per cent crude protein (The Pigeon Racing Formula).

Mustard: This is oil based seed which pigeon likes most.

Rapeseed: Only one pinch per pigeon daily is enough at evening. The rapeseed is the member of mustard family. If you serve mustard seed need not to supply rapeseed (The Pigeon Racing Formula). Pigeon pea: A neurotoxin is found in it. It causes paralysis of pigeons.

Pulse and Rice broken: This is another good feed. Mostly this is chemical free and healthy protein for pigeons.

Oyster dust: This is important for pigeons' minerals mainly calcium. Huge dust and other germs can find here. So, be very conscious during providing our pigeons.

Paddy: Its long bristles are more dangerous for pigeons. Sometimes, it attaches to pigeons' gullet which causes scar or abscess. Pigeons get suffer and sometimes die.

Safflower: Safflower seed are now available in Bangladesh which is oil based seed.

Millets: Proso and Japanese millets are common in Bangladesh which normally use for budgerigar (one kind of parakeet).

\subsection{Serving Method}

Low cost and very effective disinfectants are bleaching powder, potash and lime. Clean your farm once in a week and once in a year with strong disinfectants. For egg laying use mud pot with soft cloth but not uses newspaper because its smoothness may cause splay legs of the squab. For semiintensive rearing system daily two times feeding is required. Morning 8 am and evening $6 \mathrm{pm}$ and after hatching upto seven days need extra mid day feeding. This time all grains should be small in size. After feeding the pot will remove from the chamber. Each pigeon takes feed maximum 60 gram a day. Regular two times group feeding is important for its physical and mental exercise. Water of pigeons should always clean because this is the major source of infection. At the time of entering in pigeonry should wear apron, goggle, musk and gloves. Bright feather, normal breathing, clean eye, movement and faeces are the points for identifying pigeons' good health. Always buy new adult pigeons. Pigeons are sexually active upto 4-5 years and within this try to make another pair which is not blood-connected. This outbreeding is important for its viability. In Kushtia, Bangladesh the serving time was found twice a day but Dinajpur this was thrice (Kabir 2013b). Squab or parental stock selling is more profitable (Hazard 1922). Only millet was served in flying pigeons but other pigeons got seven mixed feed- rice, gram, mung, millet, karar, lahdarah and juwar (Blochmann 1873). A pigeon needs carbohydrate $73 \%$, protein $12 \%$, fat $5-15 \%$, calcium $1 \%$ and phosphorus $0.5 \%$ respectively (Walker).

Table1. Serving feed and its value

\begin{tabular}{|c|c|c|c|c|}
\hline Age (days) & Mode of feed & Stages & Protein $(\%)$ & Fat (\%) \\
\hline $1-7$ & Pigeon milk & \multirow{3}{*}{ Growing } & \multirow{7}{*}{13} & \\
\hline $8-21$ & \multirow[t]{2}{*}{ All items but small in size } & & & \\
\hline $22-30$ & & & & \\
\hline $31-180$ & \multirow{4}{*}{ As usual } & Moulting & & - \\
\hline \multirow{3}{*}{181 and then } & & Courtship & & \\
\hline & & Nesting & & \\
\hline & & Incubating & & 5 \\
\hline
\end{tabular}

Source: Practical Feeding for Performance by Dr Colin Walker 
Table2. Feed with major ingredients (per $100 \mathrm{~g}$ )

\begin{tabular}{|l|l|l|l|}
\hline Feed & Carbohydrate & Protein & Fat \\
\hline pea & 58.2 & 21.9 & 0.9 \\
\hline corn & 70.3 & 9.3 & 4.3 \\
\hline wheat & 71.1 & 12.3 & 1.8 \\
\hline millet & 64.7 & 11.8 & 3.3 \\
\hline safflower & 138.93 & 56.07 & 321.79 \\
\hline rapeseed & 12 & 8.2 & 0.8 \\
\hline
\end{tabular}

Source: The Pigeon Racing Formula, except safflower and rapeseed

Table3. Types of feed with components and parts

\begin{tabular}{|c|c|c|c|c|c|c|}
\hline \multirow[t]{2}{*}{ Type of feed } & \multicolumn{6}{|c|}{ parts } \\
\hline & pea & corn & wheat & safflower & rape & millet \\
\hline Standard mix & 20 & 10 & & & & \\
\hline Young bird & 20 & 15 & 15 & 5 & 2 & 2 \\
\hline Moulting mix & 16 & & 15 & 5 & 1 & 1 \\
\hline Distance mix & 15 & & 15 & 10 & 1 & 2 \\
\hline breeding & 29 & & 15 & 5 & 1 & 2 \\
\hline
\end{tabular}

Source: The Pigeon Racing Formula

Table4. Kcal for a pigeon

\begin{tabular}{|l|l|}
\hline Feed & Kcal $(100 \mathrm{~g})$ \\
\hline wheat & 327 \\
\hline corn & 86 \\
\hline millet & 378 \\
\hline rapeseed & 70 \\
\hline pea & 136 \\
\hline safflower & 518 \\
\hline rice & 365 \\
\hline Total & $\mathbf{1 8 8 0}$ \\
\hline Needs maximum 60 g daily & $\mathbf{1 6 1 . 1 4 ( 6 0 ~ g )}$ \\
\hline
\end{tabular}

\section{SUMMARY}

Pigeon rearing in Bangladesh mainly based on hobby but not on commercial issue. If we establish a real pigeon farm it reduces our economic losses and unemployment status. If it is possible to establish an ideal market for pigeons' feed it will good for better productivity. For providing huge vitamins pigeons are losing their normal viability. Soiled feed is not good for pigeons, it causes health hazards. Cryptococcus, psittacosis, gastroenteritis, salmonellosis, aspergillosis, histoplasmosis and toxoplasmosis are very common in pigeons. Water should change twice daily. In the month of January, July-September and November-December is the moulting period. Pigeons take rest in September to October. For racing April to September is the best and the breeding season is from February to May. In some places pigeons are the breeding barrier to galah and other parakeets. There is no shortcut for pigeon milk but $16 \%$ chicken crumble after blending may use for the chicks in morning and night (Casey 1988). Pre-laying/hatching/suckling stages corn $6 \mathrm{~kg}$, wheat $4 \mathrm{~kg}$, black pea $2.5 \mathrm{~kg}$, Japanese millet $0.5 \mathrm{~kg}$, broiler feed $1 \mathrm{~kg}$, mustard $250 \mathrm{~g}$ and green pea $0.5 \mathrm{~kg}$ is suitable (Kabir 2013a).

\section{REFERENCES}

Blochmann H. 1873. The Ain I Akbari by Abul-Fazl Allami. The Asiatic Society of Bengal. Vol 2: Amusements by Pigeon Flying.

Casey V. 1988. Hand feeding fancy pigeons. San Martin CA.

Hazard FA. 1922. Profitable pigeon breeding. American Pigeon Journal Company. 236 pp. 
Kabir MA. 2013a. Productivity of crossed indigenous pigeon in semi intensive system. Basic Res. J. Agric. Sci. Rev. 2(1): 01-04 pp.

Kabir MA. 2013b. Productivity, management and marketing of pigeons in pet shop. J. Agric. Econ. Dev. 2(4): 147-153.

Walker C. Practical Feeding for Performance.

www.teurlings.com

Citation: M. Ashraful Kabir, "Pigeons' Feed at their Various Stages", International Journal of Research Studies in Zoology, vol. 4, no. 2, p. 21-24, 2018. http://dx.doi.org/ 10.20431/2454-941X.0402005

Copyright: (C) 2018 Authors. This is an open-access article distributed under the terms of the Creative Commons Attribution License, which permits unrestricted use, distribution, and reproduction in any medium, provided the original author and source are credited. 